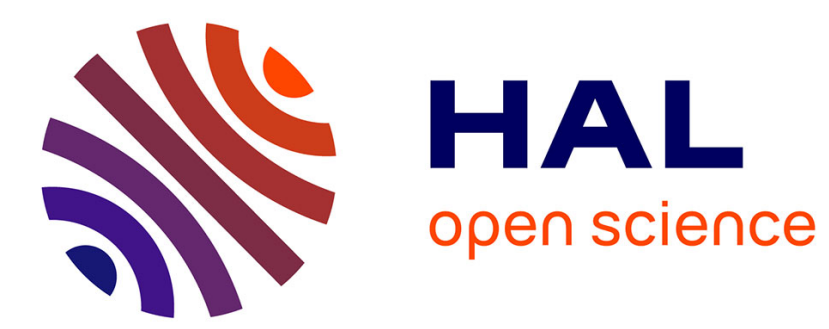

\title{
Kabyle in Arabic Script: A History without Standardisation \\ Lameen Souag
}

\section{To cite this version:}

Lameen Souag. Kabyle in Arabic Script: A History without Standardisation. Creating Standards, De Gruyter, pp.273-296, 2019, 10.1515/9783110639063-011 . halshs-02945641

\section{HAL Id: halshs-02945641 https://shs.hal.science/halshs-02945641}

Submitted on 22 Sep 2020

HAL is a multi-disciplinary open access archive for the deposit and dissemination of scientific research documents, whether they are published or not. The documents may come from teaching and research institutions in France or abroad, or from public or private research centers.
L'archive ouverte pluridisciplinaire HAL, est destinée au dépôt et à la diffusion de documents scientifiques de niveau recherche, publiés ou non, émanant des établissements d'enseignement et de recherche français ou étrangers, des laboratoires publics ou privés. 


\title{
Lameen Souag
}

\section{Kabyle in Arabic Script: A History without Standardisation}

\begin{abstract}
The history of writing Kabyle, the largest Berber variety of Algeria, is often reduced simply to the history of the development of its currently dominant Latin orthography; Kabyle before the $20^{\text {th }}$ century is often viewed as essentially an unwritten language. This oversimplification obscures an extensive, though somewhat peripheral, corpus of Kabyle written in Arabic script starting before the $19^{\text {th }}$ century and continuing in some contexts up to the present. Unlike Berber varieties in some other regions, however, Kabyle shows few signs of ever having developed a standard Arabic-script orthography, and the transcription conventions used show little or no continuity between manuscripts from different periods. This lack of standardisation reflects discontinuities in the region's educational and political history, in combination with certain differences between Kabyle and Arabic phonology.
\end{abstract}

\section{Introduction}

As might be expected from Arabic's long history as the dominant literary language of North Africa, Berber languages have frequently been written in Arabic script. In at least two regions during the pre-colonial era, such writing went beyond the sporadic quoting of words or poems and came to be used for a significant corpus of largely religiously motivated manuscripts: the Sous Valley of Morocco in the west, and the Ibādịi areas of Libya and southern Tunisia in the east (Boogert 1997; Brugnatelli 2011). This contrasts strikingly with the most populous Berber-speaking region between them, Kabylie in north-central Algeria. Relatively few Berber manuscripts in Arabic script have been reported from the area, even though it is known to have contained many zaouias (religious colleges) with substantial manuscript collections, and the colonial-era research tradition that provided Western academics with their first glimpse of the Sous and Ibādị manuscript traditions (Luciani 1893; Calassanti-Motylinski 1905) treated Kabyle as essentially an unwritten language. In present-day Kabylie too, there is little awareness of any history of writing Kabyle in Arabic script; Haddadou (2004), of the University of Tizi-Ouzou, devotes a whole section of his L'alphabet berbère to the Arabic alphabet, alluding to Moroccan, Libyan, and Mozabite examples, yet mentions no examples of its use for Kabyle. 
Contrary to the impressions of colonial-era researchers and modern Algerians alike, however, several Kabyle manuscripts in the Arabic script survive. They are strikingly similar in their content and purposes to the better-known Sous and Ibādị materials, although rather less numerous. Moreover, the practice of writing Kabyle using Arabic script has continued in some contexts even up to the present day, despite being rejected by most activists. Nevertheless, a close examination of the orthographic conventions used reveals sharp discontinuities. While individual materials produced in similar circumstances show some signs of standardisation, such embryonic conventions have rarely been maintained for long. This lack of standardisation, and the rarity of Kabyle manuscripts in Arabic script relative even to other Berber varieties, seem to be the result of two factors: the sharp discontinuities in the region's educational and political history over the past two centuries, and the specific differences between Arabic and Kabyle phonology.

\section{Contexts of literacy}

By the start of the $19^{\text {th }}$ century, the region of Kabylie, largely independent of the nominally Ottoman central government in Algiers, was covered by an extensive network of zaouias (timcemmert in Kabyle) - religious colleges providing a brief primary education to large numbers of children, and a higher education to the minority who stayed longer. Their curriculum included literacy, memorisation of the Qur'an, Arabic grammar, Sufism, Maliki law, hadith, interpretation of the Qur'an, arithmetic, geometry, astronomy, and poetry (Daumas 1847, 61-63). Colloquial languages were of little concern to this educational system, whose core texts were in Classical Arabic and whose scholars in turn normally wrote in Classical Arabic. However, an important function of graduates was to provide religious guidance in Kabyle to non-Arabic-speaking lay people, and in some cases this motivated them to write down Kabyle texts of their own composition.

The French conquest, starting in 1830 with the occupation of Algiers but not encompassing the Kabyle heartland until 1857, had a disruptive effect on this system from the start. Parts of the elite fled to Syria, preferring exile to French rule, and villages and mosques were destroyed in the process of conquest (cf. Hanoteau 1867, 144). In order to govern the newly conquered areas, the French state found it necessary to study Kabyle, resulting in a flurry of publications incorporating Kabyle text to varying degrees; these were not, however, aimed at a Kabyle audience.

In 1871, Shaykh El-Mokrani and Shaykh Aheddad led a major rebellion against France, which at its peak involved not only their native region, eastern Kabylie, but 
most of central and eastern Algeria. When France finally defeated them in 1872, the consequences for the region were dire. A heavy punitive tax was imposed, beggaring many families, and lands owned by tribes and foundations - including zaouias - were confiscated by the state. Leading rebels, including major religious scholars, were exiled or executed, and restrictions were imposed on Islamic education. In such a situation, the resources available to the zaouias, and the prospects for their graduates, were a fraction of what they had formerly been.

Meanwhile, a new educational system was beginning to provide more attractive prospects. Between 1873 and 1883, the Pères Blancs opened eight Catholic schools in Kabylie; the French government followed suit in 1882, opening another eight state schools (Dirèche 2007). In these schools, the language of instruction, and more generally of literacy, was French; together with their modern vocational focus, this qualified their graduates for subaltern positions within the colonial economy. These schools were attended by only a small minority, but their graduates' relative prosperity gave them an importance out of proportion to their numbers. Starting in the early $20^{\text {th }}$ century, the importance of French was increased by labour migration to France, as remittances became a major economic resource for Kabyle villages. Somewhat later, the Association of Muslim Ulama, founded by Ben Badis in 1931, attempted to redress the balance by expanding Islamic education and shifting it towards a modernised curriculum taught in Arabic (Heggoy 1973).

In 1948, the Algerian literacy rate, excluding French citizens, was only 6\% (United Nations 1955, 436). It was left to the War of Independence (1954-1962) to change this situation. The outbreak of the revolution was itself enough to provoke belated reforms; with the Constantine Plan of 1958, France attempted to appease and remould Algerian public opinion by, among other things, building new schools and increasing enrolment. After independence in 1962, the pace of change accelerated: the new Algerian government extended education throughout the country, making literacy one of its highest priorities. The language of instruction was initially usually French, since, at independence, most of the small minority of graduates in subjects other than Arabic and Islamic studies had studied in French and had little command of Standard Arabic. However, the government pushed hard to change the language of instruction to Arabic, despite opposition from some of those educated in French. By the end of the 1980s, all levels up to the end of secondary school, as well as many university subjects, were taught in Arabic.

Berber, however, was treated rather differently. The post-independence government viewed the idea of Berber identity as divisive, and saw no place for the language in education; the only appropriate arenas for its public use were oral contexts such as radio broadcasting or music, and even there it was put under 
pressure. In combination with other factors, this helped provoke increasing hostility in Kabylie to the government's education policy; one of the era's first largescale protests, in 1980, was triggered by the government's banning a university lecture on Berber poetry. Massive emigration from rural areas to the largely Arabicspeaking cities throughout this period led to extensive language shift among emigrants' children, compounding the feeling that Kabyle was under threat.

In 1988, the government was forced by budgetary problems and popular protests to open up the political arena to independent parties and newspapers, creating new options for the use of Kabyle in writing. In 1995, after a large-scale school boycott in Kabylie compounded the multiple crises then facing the state, it conceded the gradual introduction of Tamazight teaching into selected schools (Zeroual 1995). Over the early $21^{\text {st }}$ century, it went further, declaring Tamazight first a national language (Bouteflika 2002), and finally an official one (Bouteflika 2016). In theory, 'Tamazight' refers to a language of which all Berber varieties are considered to be dialects. In practice, the Tamazight of most government textbooks and of books by Kabyle speakers - which make up the large majority of Berber publishing in Algeria - is simply Kabyle with a number of Arabic or French loans replaced by neologisms. Even now, Tamazight occupies a very limited place in the educational system; it is taught as an optional subject, not available in all schools, and has not been adopted as a language of instruction for any other subject. However, Tamazight-language publishing, made possible by the post1988 liberalisation, continues.

\section{Sources}

No list of Kabyle works in the Arabic script can be guaranteed or even expected to be complete. Many potentially relevant collections remain uncatalogued, and the observed domains of Arabic script usage include contexts, such as private letters or political posters, which are rarely preserved systematically. Nevertheless, enough material is available from the past two or three centuries to yield a general picture. The distribution of this material can only be understood in the light of its educational and political contexts. 


\subsection{Indigenous efforts in the pre-colonial and early colonial periods}

\subsubsection{The zaouia tradition}

The manuscript libraries of the zaouias of eastern ('Petite') Kabylie have yielded a small but significant number of manuscripts in Kabyle. None include dates, unfortunately; some can be shown to date to the $19^{\text {th }}$ century, while others are thought to predate this period, but in most cases no solid evidence is available. The best documented ones are the religiously focused materials from the collection of Shaykh Lmuhub Ulahbib of Tala Uzrar (near Bejaia), born in 1822 (Aïssani 1998), some of which may predate the $19^{\text {th }}$ century. 476 manuscripts in this collection have been catalogued (Mechehed 2007), although this does not reflect the full picture, since some manuscripts have passed into other hands, and many were burned by French troops in 1957. Most of this collection is in Arabic, but it includes five Kabyle manuscripts: three copies of translations of al-Sanūsī's Creed (KA 21, KA 22, TIA 08), of which the oldest (KA 21, Fig. 1) has been addressed in detail by Gutova (2011); an anonymous poem about the virtue of knowledge by Said Ali Cherif, born 1820 (LIT 21/2); and a child's note (DVS 09). Luciani $(1893,159)$ attests to the existence at his time of a Kabyle translation of the same work at the zaouia of Sidi Yahia ben Hamoudi, among the Ait Ourthilane (which he describes as the only example of a Berber Islamic manuscript in Algeria). GEHIMAB $(2006,5)$ mentions another Kabyle creed in manuscript found at the zaouia of Tilmiouine (Ouzellaguen), and the Ministry of Religious Affairs $(2009,24)$ gives a barely legible photograph of another theological manuscript in Kabyle, cited as belonging to the family of Shaykh Oubelkassem of the zaouia at Boudjelil (bombed by the French army in 1956). Another religious poem, from the library of Shaykh Aheddad, is mentioned in Aïssani (2012). Manuscript no. 3066 of the Bibliothèque Nationale d'Algérie is described by GEHIMAB $(2006,2)$ as a 10 -page verse text on fiqh in the Kabyle dialect of the Soummam valley; the photo is illegible.

A rather different genre, equally motivated by the needs of zaouia students, is represented by the Algerian Arabic-Kabyle wordlist from the library of Cheikh Aheddad, partly reproduced by $\operatorname{GEHIMAB}(2006,5)$ and transcribed and analysed by Aïssani (2012). Zaouias often attracted students from outside the region, who would have needed to learn Kabyle for practical purposes.

Many early North African Arabic-language texts, such as the early $18^{\text {th }}$ century pharmacopoeia of Ibn Ḥamādūsh (2001, 57, 83), contain scattered words in Berber, commonly proper names or plant names. While such transcriptions are of limited 


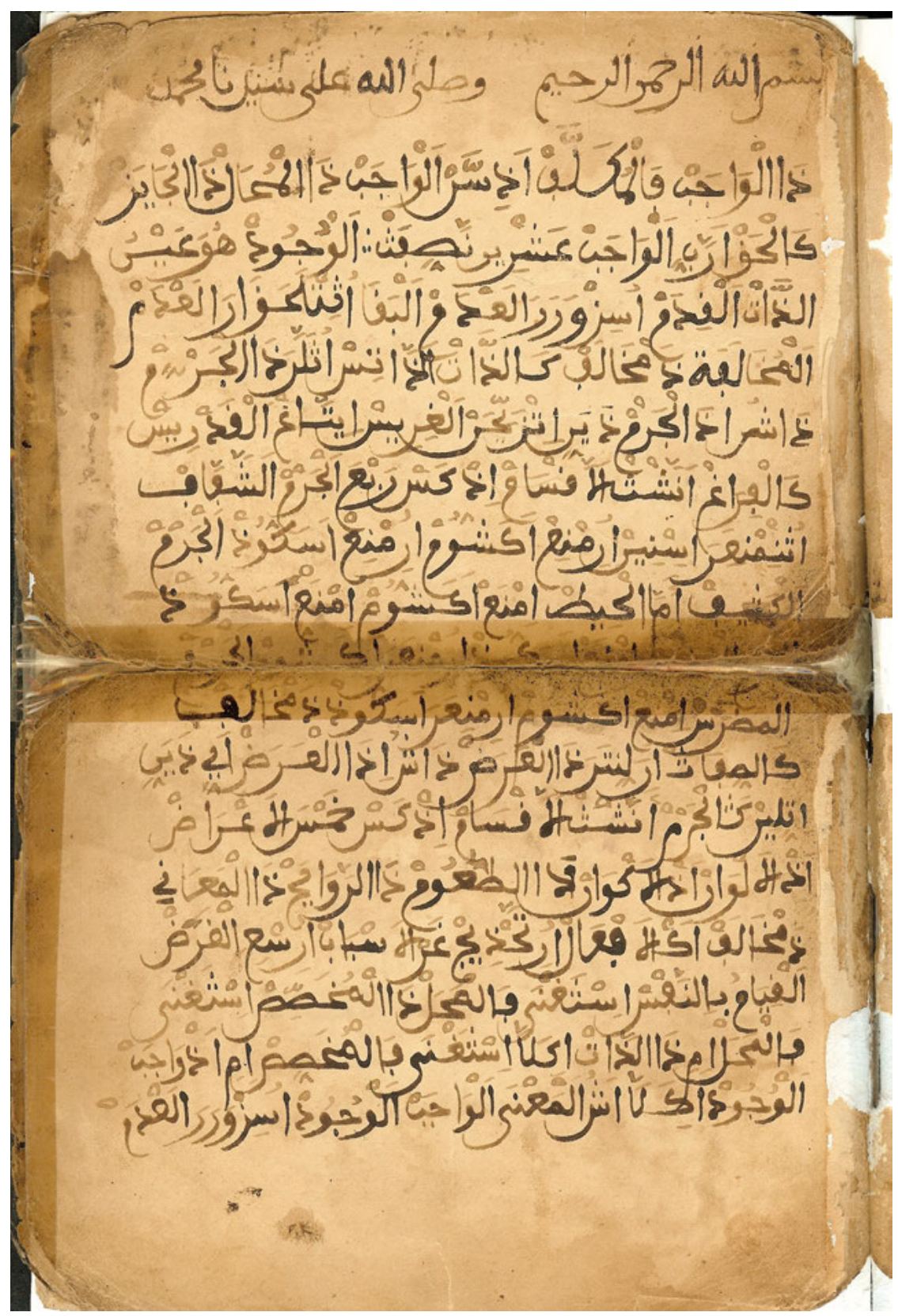

Fig. 1: First page of manuscript KA 21 from the Lmuhub Ulahbib Collection (Tala Uzrar, AinLegradj, Bejaia, Algeria), a Kabyle translation of al-Sanūsī‘s creed. ( ) Djamel-Eddine Mechehed. 
value, they too may serve as evidence for the development of orthographic conventions. The Voyage of al-Wartîlānī (1994), in which an $18^{\text {th }}$ century Kabyle religious scholar recounts his travels, is of particular interest in that its original form presumably reflected Kabyle zaouias' practices; however, a study of the author's orthographic choices would have to be based on manuscripts rather than on later printed versions.

\subsubsection{Customary law codes}

At least since the Ottoman period, some Kabyle villages created manuscripts summarising their customary law, or qanun, a phenomenon recently surveyed by Gahlouz (2011). These were most often written down in Arabic, e.g. the qanun of the Maatka copied in 1859 (Millot 1922), or the pre-colonial qanun of the Ait Hichem dating to the 1830s (Millot 1928). Occasionally, however, they were written in Kabyle; the present survey examines the late $19^{\text {th }}$ century qanun of the Ait Ali Ouharzoune scanned by Brugnatelli (2006) and partly translated (Anonymous 2009). Another reported example is that of the Ait Ouagennoun (Bernard and Millot 1933; Ould-Braham 1986). Unlike the zaouia manuscripts, these cases come from western ('Grande') Kabylie.

\subsection{Colonial efforts}

\subsubsection{Language teaching materials}

Given that Europeans and Americans are typically much more familiar with the Latin alphabet than with the Arabic one, it may appear paradoxical that textbooks and articles intended for their benefit made frequent use of the Arabic script. This fact, however, is important for the light it sheds on contemporary Kabyle practice. The earliest cases justify this practice on the basis of the speakers' own habits; thus Hodgson $(1834,38)$ writes somewhat paradoxically 'The Berber language, having no literature, has properly no alphabet of its own. It is written nevertheless by means of the Arabic characters, which are generally used for that purpose', while the dictionary of Brosselard (1844, II) - produced by a committee including one Kabyle, Sidi Ahmed ben el Hadj Ali of Bejaia - describes the Arabic orthography used as 'the system of transcription that appears most widely accepted', calling it 'the Berber alphabet' (author's translations, here and henceforth). Later works are more dismissive, describing Kabyle as an unwritten language (Delaporte 1836, 89; Ben Sedira 1887, III; Boulifa 1897, II), and presenting the writing of Kabyle in Arabic script as an occasional makeshift of the marabout class rather than a well-rooted practice. General Hanoteau's (1858) influen- 
tial grammar of Kabyle did much to popularise this view: he states that ' $[\mathrm{t}] \mathrm{hose}$ who speak it borrow its characters from the Arabic alphabet, when they want to express their ideas in their language in writing, which they moreover do only very rarely, and always with a certain distaste. Kabyle, they say, is spoken, not written' (Hanoteau 1858, 1-2), and later added for good measure that 'All efforts made to find a book written in this language have been, and no doubt always will be, fruitless' (Hanoteau 1867, II).

Nevertheless, Hanoteau continued to include Arabic transcriptions in parts of his works, justifying them on the grounds that they make it possible for the learner to get a speaker of Berber to read the words written, and thus to correct the learner's pronunciation: 'This transcription, nonetheless, will not be lacking in utility for people who want to study the Kabyle language; it will allow them, in effect, to get the texts read for them by a Kabyle' (Hanoteau 1867, XII). The practicality of this solution is confirmed by other data. Rinn (1887) presents two Kabyle poems attacking Cheikh Aheddad, anonymously sent in Arabic script to a French general in 1872; these suggest that, at that period, even the small minority of Kabyle speakers who wanted to be seen as vocally pro-French were more accustomed to Arabic script.

The prolific output of René Basset would keep the practice of Arabic transcription going for some decades longer. In his Manuel de langue kabyle (1887), as throughout his extensive publications on Berber, he used Arabic characters alongside Latin transcription, on the grounds that (p. VIII) '[T] he natives, [w] hatever one may do, will not abandon the use of the Oriental characters', and that it allows problematic short vowels to be ignored in writing. In the meantime, however, this justification was becoming unnecessary: the demands of French administration were creating a minority of Kabyles literate in French.

For this new group, uncomfortably poised between the indigenous and French societies, the use of Arabic script could no longer be taken for granted. In a short grammar, Ben Khouas (1881, 5-6), presents a paragraph-long argument to conclude that '[s]ince [...] the Kabyles have much more frequent relations with the French than with the Arabs, especially when there is occasion to write something, it is preferable in every way, for writing Kabyle, to use French characters'. Textbooks by others in this situation at the same period, such as Ben Sedira (1887) and Boulifa (1897), dispense with Arabic characters entirely, or, like Boulifa (1913, 351), confine them to a single page by way of preparation for examinations. The same trend is observed in contemporary French linguists' work; Mouliéras (1892; 1893) uses Latin characters exclusively to transcribe the Kabyle stories dictated to him by informants he describes as illiterate, as does Gourliau (1893), while Luciani (1899, 33) publishes only the Latin transcription of poems he had actually received in Arabic transcription. In $20^{\text {th }}$ century French-language works on Kabyle, whether by Frenchmen or by Algerians, Arabic characters are almost uniformly absent. 


\subsubsection{Missionary materials}

Insofar as Christian missionaries' choice of orthography reflects their perception of existing usage, it casts light on Kabyle orthographic preferences in a similar way to language learning materials. However, sectarian factors also appear to have been relevant; Catholic sources consistently avoid Arabic script in this region, while Protestant ones show greater variability.

The earliest attempts to render parts of the Bible into Kabyle, from Arabic, took place at the behest of the American vice-consul Hodgson. The (Muslim) translator he commissioned, the marabout 'Si Hamet' of Bejaia, wrote his translation in the Arabic script. Parts of these (Anonymous 1833) were printed in a modified Arabic script and distributed in Algeria shortly after the French conquest, while another portion was later printed for purely linguistic uses (Newman 1847).

Serious efforts at Christian proselytisation in Algeria started a generation later, in 1868, when the newly appointed Catholic Archbishop of Algiers, Cardinal Lavigerie, founded the Pères Blancs; starting in 1873, they also established village schools in Kabylie (Dirèche 2007). From the start, their efforts, liturgical (Allemand-Lavigerie 1868; 1869) or lexicographic (Creusat 1873; Olivier 1878; Huyghe 1901), made exclusive use of Latin characters, again characterising Kabyle as an unwritten language.

Protestant evangelisation - initially based at Djemaa Saharidj near Tizi-Ouzou - largely followed the Catholic lead in this respect, justifying the choice on the grounds that French schools were in any case spreading literacy in the Latin script by then (Rutherfurd and Glenny 1900, 146; Cuendet, Hocart and Lamb 1893). Nevertheless, they hedged their bets with a supplementary printing of Mark and Luke in Arabic script (British and Foreign Bible Society 1904), specifically intended for students from traditional Islamic schools (Canton 1904, 16): 'Stirred by the energy of western life, the marabouts taught the Kabyle lads the Arabic character, and for these a transliteration of St Luke was in progress'. This would be the last missionary publication in Kabyle using Arabic script, as far as I have been able to find.

\subsection{The early $20^{\text {th }}$ century}

\subsubsection{Poetry}

One of the earliest and most important printed works by a Kabyle author aimed partly at a Kabyle audience, Boulifa's (1904) anthology of Kabyle poetry, uses both Latin and Arabic characters. Since the author's pedagogical works intended for Frenchmen do not include Arabic script, this choice was most likely intended 
to make the poems legible to a wider audience of literate Kabyles. Yet the expansion of French education in the region starting from 1880 (Dirèche 2007), along with the closing of zaouias, would leave the Arabic characters meaningless to later generations. Mouloud Feraoun (1960,10-11) bears eloquent witness at once to Boulifa's success in appealing to a Kabyle audience and to the change in educational patterns that made this practice obsolete:

They are incapable of reading the poems gathered by Boulifa in the Arabic transcription; if they tackle the French transcription, they can be sure of reading them well only when it comes to a poem that they already know [...] It is "the Book", the only book of young Kabyles. You find it in the villages, old and venerable, as it was published more than half a century ago [...] It is never complete; a number of its missing pages have been offered to a friend, to continue their clandestine career in others' hands. ${ }^{1}$

The use of Arabic script would still be continued, however, by those Kabyles who opted for a traditional or reformist (Ulama) education. Yacine (1987) presents an extensive corpus of reformist Islamic and nationalist poetry in Kabyle by Qasi Udifella, originally written down in vocalised Arabic letters by Hadj Boubekar in the 1940s in the Biban region in the extreme east of Kabylie. The choice of Arabic characters was natural, given their political alignment.

\subsubsection{Popular music}

In the 1950s and 1960s, Kabyle song titles (and sometimes lyrics) could often be found in Arabic script, as can readily be seen by examining the LPs of Cherif Kheddam, Slimane Azem, or El Hasnaoui. In fact, Cherif Kheddam, educated at the zaouia of Boudjelil in eastern Kabylie, often wrote his own lyrics in Arabic script (GEHIMAB 2006). This minor domain of Arabic-script Kabyle becomes less prominent in the 1970s (Idir's albums, to take an influential example, simply use Latin script), and later vanished almost completely.

1 Les poèmes recueillis par Boulifa, ils sont incapables de les lire dans la transcription arabe ; s'ils s'attaquent à la transcription française, ils ne sont sûrs de bien lire que lorsqu'il s'agit d'un poème qu'ils connaissent déjà [...] Il est “le Livre”, l'unique livre des jeunes Kabyles. On le trouve dans les villages, vieilli et vénérable, tel qu'il fût édité, il y a plus d'un demi-siècle [...] Il n'est jamais complet : nombre de ses feuillets manquants ont été offerts à un ami pour poursuivre en d'autre mains leur carrière clandestine. 


\subsection{Official recognition}

The post-independence Amazigh identity movement, reacting against the uniform Arab identity urged on them by the Algerian state, conspicuously avoided the use of Arabic script. The Neo-Tifinagh script proposed by the Académie Berbère quickly attained emblematic status for signs and mottos, while the Latin orthography later popularised by Mouloud Mammeri (1976) came to be generally adopted for longer works. However, political liberalisation following 1988 created arenas outside of Amazigh activism for the written use of Kabyle; already during the 1989-1990 election campaigns some parties created posters with slogans in Kabyle in Arabic script (not examined here). Soon afterwards, the Algerian state, facing intense pressure on multiple fronts, offered the Amazigh activists a limited compromise. Since 1995, the Algerian state has provided limited teaching of Tamazight (conceived as a single language) in selected schools; since 2002, Tamazight has been recognised as a national language, and in 2016 it was declared an official one as well.

\subsubsection{Educational materials}

The decision to teach Tamazight required the creation of textbooks and dictionaries acceptable to the state. As such, it brought previously unconcerned parties into the orthography debate. While the use of Arabic script was by and large strongly opposed by Amazigh activists, particularly in Kabylie, it was strongly favoured by significant segments of the state and of Algerian public opinion outside the region. The dictionary of Tagamount (1995), published just in time for this decision, reflects the debate: while primarily using Latin characters, it provides an Arabic transcription in the Kabyle-French/Arabic section, alongside the Arabic translations. This grudging concession to Arabic would not be followed up in subsequent dictionaries, however: while Kabyle dictionaries have since become a routine sight in Algerian bookstores, even those that give Arabic translations almost always avoid giving Arabic transcriptions.

Notwithstanding the widespread preference for Latin script (Sini 2004), Kabyle supporters of the Arabic script can still be found. A notable example is Salah Belaid, of the University of Tizi-Ouzou. He devotes nearly half a book (Belaid 1999) to the issue of which writing system to choose for Berber, coming down strongly in favour of Arabic. By way of examples, he gives a text transcribed into Tifinagh, Latin, and Arabic characters (159-166) and a glossary of neologisms drawing extensively on previous authors' work (215ff). Like most other writers on the subject of which script to choose for Kabyle, however, he does not appear 
to have published any books in Kabyle, so there is little incentive for would-be readers to learn his orthographies.

Up to the present, the disagreement over script choice has been resolved by making official materials for the study of Berber available in three scripts: Latin, Arabic, and Tifinagh. In practice, Latin script overwhelmingly predominates in Kabylie, but official examples of the use of Arabic script can still be seen, e.g. Ministry of Education (2003), Hrouch et al. (2010). As will be seen below, the Arabic orthography used in these textbooks, described in detail by Gaci (2011), is rather eccentric, being chosen basically to maximise compatibility with the Latin transcription, and does not correspond to any of the practices seen elsewhere.

\subsubsection{Religious materials}

The post-1995 climate of relative openness to Tamazight affected not only the educational system, but also a domain whose control is almost equally important to the state: Islamic religious publications. The preference for Arabic orthography was, unsurprisingly, particularly strong in this domain - although even here, non-statefunded publications have used Latin script. A group led by the Kabyle religious scholar Si Mohand Tayeb has published first selections from the Qur'ān (2003) and later a full translation (2012), printed in Saudi Arabia with funding from Algeria's Ministry of Religious Affairs. In this work the Arabic script is used, with some additional characters. The decision to write in Arabic script attracted criticism from Kabyle activists, but was vigorously defended by the author (as quoted in Chachoua 2010): 'My principal long-term goal is to defend Berber against those who want to turn it away and distance it from Islam. [...] I have often, in many published articles and letters to various political authorities, called for the adoption of Arabic letters for writing Berber, and I would do the impossible to make this happen'. Rebahi (2009), in a booklet funded by the same ministry, gives two short religious poems in Kabyle, written in Arabic script, with translations.

\subsubsection{State media}

A national radio channel using Tamazight (mainly but not exclusively Kabyle), Radio 2, has been maintained since independence. The question of script choice hardly arises for broadcasting, but since at least 2011 this channel has also had a webpage (Radio 2) at the national radio service's website. At no point has this page been translated into Kabyle or any other Tamazight variety. From 2011 to 2013, it was bilingual in Arabic and French, with Kabyle programme titles and headings 
transcribed in Arabic script on the Arabic site and in Latin script on the French site. By 2014, this was no longer the case: since then the Radio 2 page has been available only in French, not in Arabic, and the programme titles and headings (still in Kabyle) are transcribed in Latin script (and later also Tifinagh). The only remaining trace of Arabic script in 2014 was the station motto at the top of the page, transcribed in Tifinagh, Arabic script, and Latin script - and by 2017 this had been replaced by the name of the station in Tifinagh script plus translations into French and Arabic. More recently, a Tamazight TV channel (TV 4) has been created; this station too makes frequent use of Arabic script to transcribe Tamazight titles or slogans, including Kabyle ones, but the texts in question remain very short.

In 2013, the state-owned primarily Arabic-language newspaper Ech Chaab, founded in 1962, started carrying columns in Tamazight written in Arabic script (Rubrique Radar 2013). Some, but not all, of these columns were in Kabyle, e.g. Lakhdari (2013).

\subsubsection{Books on heritage}

The most conspicuous contributor in this domain is the historian and ex-FFS deputy Mohamed Arezki Ferad. His history of his native Azeffoun (2003), primarily written in Arabic, includes many Kabyle poems and sayings written in Arabic script. In his study of Tipasa Berber proverbs (Ferad 2004), an attempt to document the oral traditions of a Berber dialect falling outside the Kabyle continuum proper, he acknowledges that the Latin script has taken the lead at present, but vigorously defends his choice of the Arabic script, arguing that 'in view of the richness of the Berber cultural stock recorded in Arabic characters (books, contracts...) and the cultural factors that have brought together the Berber and Arabic languages, the Arabic script is a candidate for filling the principal role in the advancement and development of Berber in the future' (63). The author has gone on to produce other books focused on Kabyle heritage, including an overview of the region (Ferad 2007) and a study of Kabyle Sufi poetry (Ferad 2011). More academically oriented Arabic-medium studies of Kabyle folklore also sometimes make use of Arabic script, such as the thesis of Tabarkān (2012).

\section{Orthographic conventions and their contexts}

The number of texts written in Kabyle in the Arabic script, while not enormous, is sufficiently large to raise the question of standardisation. How have different 
authors dealt with the problem of representing phonemes with no direct Arabic equivalents? To what extent have they been influenced by one another's conventions, or more generally adopted similar conventions? When and in what milieux have standards, if any, emerged, and how long have they been maintained?

\subsection{Challenges for orthography design}

All of the phonemes of Classical Arabic as pronounced in Algeria are to be found

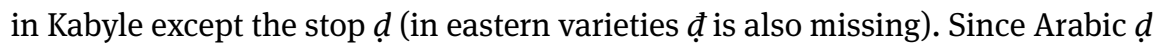
is usually pronounced $q$ in the region except in careful speech, this gives authors a choice between $d$ and $\underset{d}{d}$ to represent the phoneme $\underset{t}{d}$. Kabyle, however, also has a number of consonant phonemes lacking in Classical Arabic, most conspicuously $g$ and $z$ (shared with Algerian Arabic). It distinguishes affricates $\check{c}$, $\breve{g}$ (mainly in geminates) from fricatives $\check{s}, \check{z}$ (conventionally transcribed $c$, $j$ ), while Arabic does not (depending on the underlying dialect, Arabic ğim is regionally realised either as $\breve{g}$ or as $\check{z}$ ). It also marginally distinguishes affricates $t s, d z$ (the former is usually derived from underlying geminate $t$, while the latter is very rare) from both $t, d$ and $s, z$, while Arabic has no phonemic affricates. It has a broader distinction, usually predictable but contrastive in some contexts, between stops $(b, t, d, k, g)$ and spirants $(\underline{b}, \underline{t}, \underline{d}, \underline{k}, \bar{g})$; of the spirants, only $\underline{t}$ and $\underline{d}$ have Arabic counterparts. The distinction between plain $l, r$ and emphatic $l, r$ is marginally contrastive both in Kabyle and in Algerian Arabic (for $l$ it is arguably contrastive even for Classical Arabic), but is consistently not made in Arabic script; that between $\check{s}$ and $̌$ is even more marginal in Kabyle, and absent in Arabic. Kabyle also has a series of labiovelarised back consonants $\left(k^{w}, g^{w}, x^{w}, \gamma^{w}\right)$, with no direct equivalent in Arabic, but often corresponding in loanwords to Arabic short $u$. Of these, note that the affricates $t s, d z$ and the spirant series are not phonemic in Shilha and in Libya, simplifying the situation faced by would-be writers there.

The vowel inventory of Kabyle is rather smaller than that of Classical Arabic; whereas Arabic distinguishes short $a, i, u$ from long $\bar{a}, \bar{\imath}, \bar{u}$, Kabyle contrasts one lax vowel, a (conventionally transcribed $e$ ), with three tense ones, $a, i, u$. (In Shilha, the lax vowel no longer has any phonemic status.) Mapping the Kabyle system onto the Arabic one poses some difficulties. In Kabyle, the tense set are phonetically long in open syllables when stressed, and shorter elsewhere; this encourages a phonetic rather than phonemic transcription into Arabic characters. The lax vowel, however, is consistently short, so overtly representing length tends to create ambiguity with it. Moreover, word-finally, Arabic distinguishes $\bar{a}$ (alif mamdūdah) from à (alif maqșūrah, written with an undotted yā') on purely morphological grounds not directly paralleled in Kabyle. 


\subsection{Observed solutions}

Table 1 sums up the observed responses to the most important of the issues in 4.1, by source (for the numerals under 'Tense vowels', see 4.2.2). Note that eastern Kabyle varieties, used in several of these sources, do not have a phoneme đ. Only a limited selection of the Bible translation of 1904 was available.

Table 1: Orthographic choices by source.

\section{$\begin{array}{llllllllllllllll}\text { đa } & \mathbf{g} & \mathbf{z} & \text { ts } & \check{c} & \underline{b} & \underline{\mathbf{k}} & \overline{\mathbf{g}} & \mathbf{C}^{\mathrm{w}} & \text { Tense } & \text { ə }\end{array}$ vowels}

\section{Zaouias:}

KA 21 (Gutova 2011)

Poem in honour of Aheddad (GEHIMAB ض

2006, 3)

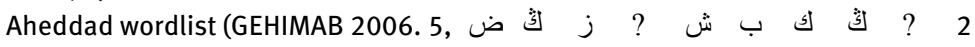

Aïssani 2012)

Customary law:

Ait Ali Ouharzoune (Brugnatelli 2006, ض

Anonymous 2009)

Language teaching:

Brosselard (1844)

Hanoteau (1867)

Rinn (1887)

Basset (1887)

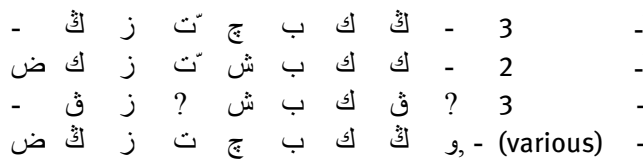

Bible translations:

Anonymous (1833)

BFBS (1904)

Early $20^{\text {th }}$ century:

Boulifa (1904)

Udifella (Yacine 1987)

4

3

\section{Educational materials:}

Tagamount (1995)-

Belaid (1999) - text

Belaid (1999) - lexicon

- 2

$$
\text { ث } 2
$$

Hrouch et al. (2003)

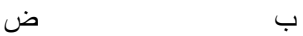

\section{Ministry of Religion:}

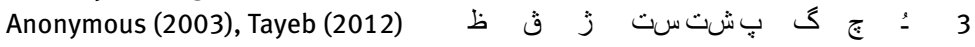

Folklore:

Ferad (2003)

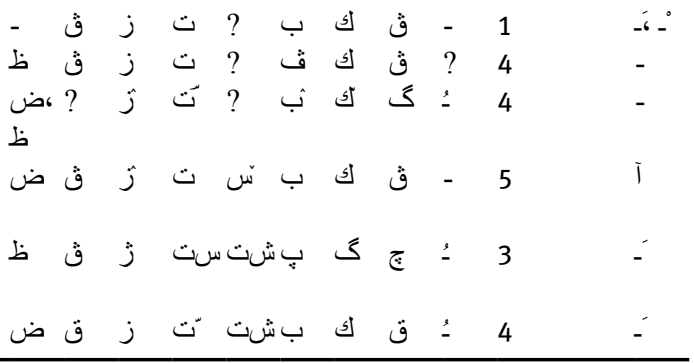


Other minor points of variation have been omitted from the table. These rarely relate to consonants, although one source - the first Bible translation (Anonymous 1833) - makes the particularly eccentric choice to represent $\underline{t}$ with a new character seemingly based on Greek theta: a $f \bar{a}^{\prime}$ shape with a dot inside the loop (not in Unicode). However, earlier sources use the maghribi script, while modern ones use naskhī; this entails a difference in the dotting of $f \bar{a}^{\prime}$ (under in maghribi over in naskhī).

More commonly, differences relate to vocalisation. Initial geminates are often written with al-, particularly for coronal consonants. Some sources, such as the qanun of Ait Ali Ouharzoune, the poem in honour of Shaykh Aheddad, and the poetry of Udifella, frequently write word-final -en using tanwin (-an). Final - $a$ is sometimes written with $\grave{a}$ or even with $t \bar{a}^{\prime}$ marbūtah, and final $-u$ with $w \bar{a} w+$ alif. The use of šaddah to mark gemination is not always consistent.

The textbook of Hrouch et al. (2003) stands out in a number of respects. While other sources normally transcribe initial epenthetic schwa using an alif, this textbook systematically omits it. Likewise, most sources write initial $i$ and $u$ with alif (usually followed by $y \bar{a}^{\prime}$ or $w \bar{a} w$ ), but this textbook uses $y \bar{a}^{\prime}+h a m z a$ and $w \bar{a} w+h a m z a$. Almost all sources write clitics as part of the same orthographic word as their host, whereas this textbook separates them with a hyphen. In all these respects, and in others to be seen below, this textbook calques the Latin script orthography that was dominant by the time of its publication.

\subsubsection{Consonants}

A majority of the consonants are shared between Arabic and Berber; as a result, most consonants are represented identically in all texts. The exceptions, however, are informative.

The consonant $\underset{d}{d}$, where present, is overwhelmingly written as $\underline{d} \bar{a} d$, whose pronunciation (except in careful speech) is the same and which has a far higher

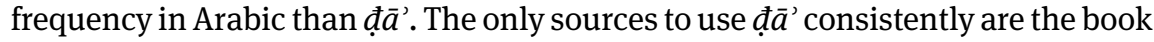
of Belaid, a linguist teaching Arabic, and the Qur'an translation, whose authors had presumably been trained in recitation and hence in careful pronunciation of Classical Arabic phonemes; both would be expected to be unusually sensitive to the distinction in "proper" Arabic pronunciation between $d$ and $\underset{\text { }}{ }$.

In sources from the $19^{\text {th }}$ century or earlier, $g$ is normally represented by a $k \bar{a} f$, with or without three extra dots. The choice to base the letter for $g$ on $k$ corresponds to traditions established in the region much earlier (cf. Ibn Khaldūn $(1969,32)$, van den Boogert (1997)). However, a three-dotted $q \bar{a} f$ is overwhelmingly predominant in $20^{\text {th }}$ century sources, anticipated by the Bible translation of 1833 (but 
not by Newman's (1847) transcription from the same source!) and by Rinn (1887). This reflects the influence of bilingualism in Algerian Arabic, where the reflex of classical $q \bar{a} f$ is often $g$ rather than $q$, and corresponds to normal modern Algerian practice in Standard Arabic when transcribing place names.

No efforts are made to distinguish $z$ from $z$ until the late $20^{\text {th }}$ century - and even in those texts, actual usage is not entirely consistent. Hrouch et al.'s use of $z \bar{a} y$ with a circumflex may be a rare instance of Belaid's work influencing others, but may represent independent innovation; in either case, a possible source of inspiration at this late period is Sorani Kurdish, which uses $\lrcorner$. and J. The Qur'ān translation's use of a $z \bar{a} y$ shape with three dots follows in the footsteps of Chafik (1990) and Baamrani (2003) for Moroccan Berber, and takes advantage of this character's presence in Unicode and in major digital fonts.

Very few sources seem to have felt any need to distinguish ts from its usual underlying source $t$. Of those that do, Belaid (who adds a small sin on top of the letter $t \bar{a}^{\prime}$ ) and the Qur'an translators (who use a cluster $t+s$ ) have already been observed to be particularly sensitive to minor details of pronunciation, while Anonymous (1833) may well have created the character (the letter shape of sin plus the two dots of $t \bar{a}^{\prime}$ ) in response to the requests of the American consul who commissioned him.

The low textual frequency of $\check{c}$ makes it difficult to generalise with confidence, but in texts predating the 1980s, it is normally represented as šin except in works produced for foreigners.The latter often (but not always) use jim with three dots, a letter borrowed directly from Ottoman Turkish. Among more recent works, Ferad and the Qur'an translators represent it as a cluster $(t+\check{s})$, again corresponding to common practice in Arabic transcriptions of place names in Algeria, while Hrouch et al. add a haček to sinn, probably calqued from the Latin orthography.

The treatment of spirants is further complicated by the existence of variation within Kabyle; not all dialects necessarily have $\underline{b}$, for example. In any case, we find that $19^{\text {th }}$ century materials consistently write $b \bar{a}^{\prime}$ in the positions where we might expect $\underline{b}$. Most $20^{\text {th }}$ century sources do the same, but Udifella and the Qur'an translators both represent it as a $b \bar{a}$ ' shape with three dots below - it is unclear whether the latter got it from the former, but in view of the religious content of Udifella's poetry it cannot be excluded. Belaid is strikingly inconsistent on this point (and the combination of $q \bar{a} f$ with three dots for $g$ and $f \bar{a}^{\prime}$ with three dots for $\underline{b}$ that he uses in his sample text creates intolerable systematic ambiguity.)

Spirant $\underline{k}$ and $\bar{g}$ are almost never distinguished from stops $k$ and $g$. Belaid makes sporadic attempts to do so, but the only source systematically distinguishing them is the Qur'an translation. The novelty of the latter's choice is clear from the signs chosen. The choice of jim with three dots for $\bar{g}$ can only reflect awareness of the Egyptian pronunciation of jim as $g$, an awareness that would have 
been unlikely in earlier periods, while that of $k \bar{a} f$ with a line on top for $k$ likewise reflects the assumption that an Algerian audience will not be familiar with the usage of this letter for $g$, an assumption which is certainly correct at present but which would have been much less well-founded in the $19^{\text {th }}$ century, when some literate people would likely have been aware of Ottoman Turkish practice.

There is little consistency in the representation of labiovelarisation even within a single text, but insofar as it is represented it is usually represented using a damma. Basset (1887) and Boulifa (1904) occasionally use a wāw instead.

\subsubsection{Vowels}

Due to the system incongruity discussed earlier, vowels are a much more conspicuous source of variation than consonants, despite being much fewer in number. The schwa is almost always written with a fatha, but for tense vowels there is considerable vacillation between short and long representations. A given word's transcription may differ even within the same manuscript, but five main distributions may be identified, falling along a continuum from preference for short vowels (greatest in early and religious sources) to preference for long ones (greatest in recent and secular ones):

1. All vowels are written short, without exception (except sometimes in Arabic loans, which optionally retain their original orthography). This is observed in the Aheddad poem, e.g. إسُفْغْنْ >isufyit> issufyit 'he got him out', أنْب >anbi> ennbi 'the prophet' (an Arabic loan!), and in Tagamount's (1995) dictionary. In this system, Arabic vowels are used purely for their quality, and no effort is made to identify length with tenseness.

2. Most vowels are written short; in the rare exceptions (more or less common depending on the source), only one vowel per orthographic word is written long (excluding Arabic loans). This vowel is always tense, and normally in a penul-

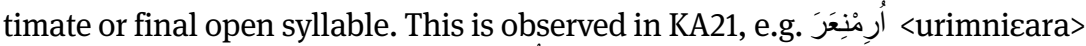

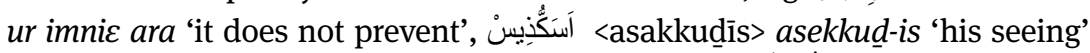

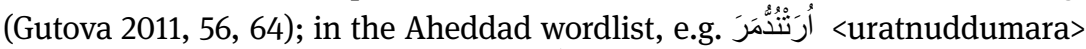

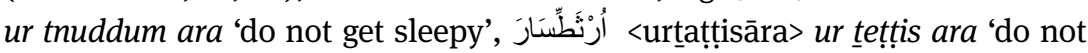

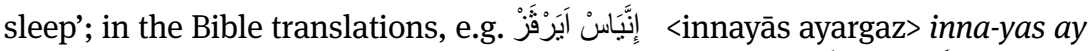

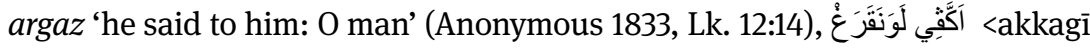
lawanaqaray> akkagi la-awen eqqarey 'thus I say to you' (British and Foreign Bible Society (1904), Lk. 15:10, quoted in British and Foreign Bible Society (1965)); and in Hanoteau (1867), e.g. ذَكْجُفَارن <dakjufār> deg (i)jufar in the lower

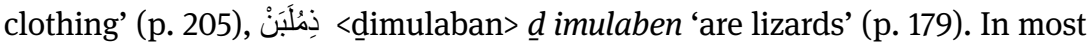
examples the long vowel seems to be stressed, and hence is in fact phonetically 
longer; this orthography thus indicates a sensitivity to the length distinction that is phonemic in Classical Arabic but merely phonetic in Kabyle.

3. If a word contains any tense vowels, usually either one or two of them is written long (although, more or less frequently depending on the source, they may also all be written short). This is observed in Brosselard (1844), e.g.

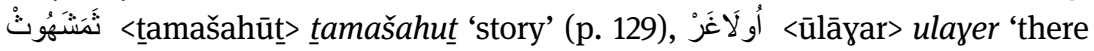
is no point' (p. 286); in the qanun of Ait Ali Ouharzoune, e.g. آيَزِيضن <ayazidd>

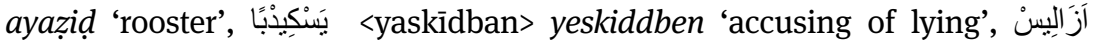
<azālīs> azal-is 'its value’; in Rinn (1887), e.g. بابور <b’bwr> babur 'Babor (place name)' (p. 58), سعوذيو >SSwdyw> s uSudiw 'with a horse' (p. 56); in Udifella's

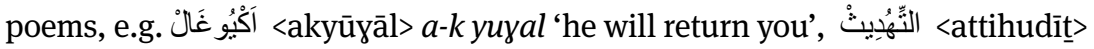
$n$ teyhudit 'of malice', بيَنْنَيَّن > yatnadiyās> yettnadi-yas 'he seeks for him'; in

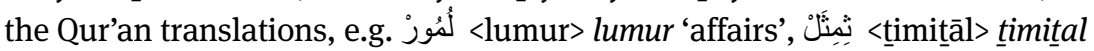
'example'. In the qanun, unusually, even schwas may optionally be written long in final syllables: يَرْوَالْ >yarwāl> yerwel 'he fled'. This practice too reflects phonetic reality to some extent, in that vowels before the main stress seem to have shorter duration.

4. All tense vowels are normally written long, except sometimes in antepenultimate or earlier positions. This is observed in Boulifa (1904), in Ferad (2003),

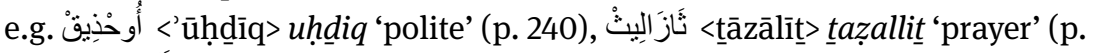
257), أََْمِيرُونْ >adamīrūh > ad-am iruh 'it will go for you' (p. 235), and in Belaid (1995), e.g. ثمليليث

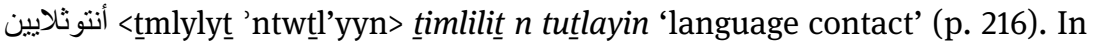
that most tense vowels are written as long, this probably reflects interference from colloquial Algerian Arabic, which has the same vowel system as Kabyle, but with schwa as the normal reflex of Classical short vowels, and tense vowels for Classical long vowels.

5. All vowels are written using matres lectionis, even schwa (only in the textbook of Hrouch et al. (2003)). This practice can be explained neither in terms of Classical nor of Algerian Arabic; rather, like much else in this textbook, is obviously calqued from the Latin orthography which by that time was predominant for Kabyle. Examples: تيخسي >tixsi> 'ewe', نئ > iآ > izem> izem 'lion'.

Basset (1887) cannot readily be placed in any one category, since he quotes texts from several different sources.

In all but the last of these systems, schwa is written using a fathah, as is $a$ in certain circumstances. This, to varying degrees, creates ambiguity between $e$ and $a$. 


\section{Conclusions}

Kabyle has repeatedly been written in Arabic script since the pre-colonial period, particularly in the east. This practice was a natural outgrowth of religious education, and as such was never suppressed entirely despite difficult conditions. However, despite a history of at least three centuries, only those conventions imported directly from Arabic are stable; where orthographic choices must be made, those choices vary substantially from one source to the next. A few longterm trends are observable, in particular the replacement of $k \bar{a} f$ with $q \bar{a} f$ as a basis for transcribing $g$ and an increasing preference for matres lectionis over diacritics in representing vowels, but most of the variation is purely individual. A necessary precondition for this variation was the existence of significant divergences between Arabic and Kabyle phonology, notably greater than those observed for Shilha. While those divergences made the task of establishing a consistent orthography more difficult in principle, the fact that no one solution to these challenges has ever been consistently adopted for long primarily reflects historical rather than linguistic facts. At no point has any one writer's or school's Arabicscript work been sufficiently widely read to be imitated, and all but the most prominent of one generation's orthographic innovations have been forgotten by the next. This is to be expected given the repeated massive upheavals that have affected education in the region and the fact that teaching Kabyle has never been a primary goal of any of its educational systems, and is unlikely to change: while the belated introduction of Kabyle teaching after 1995 has provided a powerful new tool for standardisation, the general preference among today's Kabyle-language writers and teachers for Latin makes it practically certain that this standardisation will only affect the now-dominant, and already relatively stable, Latin orthography.

This chapter's conclusions are fairly solid insofar as they concern the print era; more data on political posters and album covers would be helpful, but appears unlikely to alter the overall picture. However, data on Kabyle manuscripts, particularly those dating to the pre-colonial period, remains frustratingly scanty. There is no reason to believe that all relevant manuscripts are known, and almost all of those that have been reported in the literature are still unpublished. Any conclusions concerning manuscript practices are thus necessarily somewhat tentative, and should be tested against newly discovered or newly published manuscripts as they become available. 


\section{References}

Aïssani, Djamel (1998), 'Les écrits de langue berbère de la collection de manuscrits Oulahibib (Bédjaia)', in Etudes et Documents Berbères, 15-16: 81-99.

Aïssani, Djamel(2012), 'Le lexique manuscrit Arabe dialectal - Kabyle de la Zawiyya historique de Cheikh Aheddad', in Kamal Naït-Zerrad (ed.), Linguistique de corpus: de la constitution à l'exploitation, Paris: Inalco, 15-32.

Allemand-Lavigerie, Charles-Martial (ed.) (1868), Catéchisme du diocèse d'Alger. Algiers: Bastide. Allemand-Lavigerie, Charles-Martial (ed.) (1869), Aktab en tibratin d endjilen i idomniken tifestin ousoggas, staqebailit / Livre des épitres et évangiles pour les dimanches et fêtes de l'année en langue kabyle, Algiers: Bastide.

Anonymous (1833), Extrait d'une traduction ms. en langue berbère de quelques parties de l'Ecriture Saine : contenant XII chapitres de S. Luc. Londres: Société Biblique Britannique et Etrangère.

Anonymous (2003), Sūrat al-Fātiḥah wa-l-'Ajzā' al-Thalāthah al-'Akhīrah Qad SamiYa wa-Tabārak wa-YAmma wa-Tarjamat MaYānīhā 'ilā l-Lughah al-'Amāzīghiyyah / Translation of the Meanings of Surah al-Faatihah and the last Three Juz' of the Quran in the Kabyle (Tamazight) Language. Madinah: Mujamma al-Malik Fahd li-ṬibāYat al-Maṣhaf al-Sharīf.

Anonymous (2009), Le qânoûn des ait ali ouharzoune (en dialecte kabyle, transcrit en lettres arabes). http://aitaliouharzoune-bs.vip-blog.com/vip/article/4850323,-Le-qânoûn-des-aitali-ouharzoune(en-dialecte-kabyletranscrit-en-lettres-arabes)-.html (30 September, 2013).

Baamrani, Jouhadi Lhocine (2003), Tarjamat maSānī al-Qur'ān al-Karīm: Nūr Salā nūr / Tifawt $f$ tifawt, bi-l-luġah al-’amāzīgiyyah. Casablanca: Al-Najāḥ al-Jadīdah.

Basset, René (1887), Manuel de langue kabyle (dialecte zouaoua) : grammaire, bibliographie, chrestomathie et lexique. Paris: Maisonneuve \& Ch. Leclerc.

Belaid, Salah (1999), Fĩ al-Mas'alah al-'Amāzīghiyyah. Algiers: Dār Hūmā.

Bernard, A., and Louis Millot (1933), 'Les qanouns kabyles dans l'ouvrage de Hanoteau et Letourneaux', in Revue des études islamiques, 7: 1-44.

Boogert, Nico van den (1997), The Berber Literary Tradition of the Sous: with an edition and translation of "The Ocean of Tears" by Muhammad Awzal (d. 1749), Leiden: Nederlands Instituut voor het Nabije Osten.

Boulifa, Si Ammar ben Saïd (1897), Une première année de langue kabyle : dialecte zouaoua. Algiers: Adolphe Jourdan.

Boulifa, Si Ammar ben Saïd (1904), Recueil de poésies kabyles (texte zouaoua) traduites, annotés et précédées d'une étude sur la femme kabyle. Algiers: Adolphe Jourdan. http:// www.e-corpus.org/notices/104452/gallery/880441.

Boulifa, Si Ammar ben Saïd (1913), Méthode de langue kabyle : cours de deuxième année. Etude linguistique et sociologique sur la Kabylie du Djurdjura. Texte zouaoua suivi d'un glossaire. Algiers: Adolphe Jourdan.

Bouteflika, Abdelaziz (2002), 'Loi nº 02-03 du 27 Moharram 1423 correspondant au 10 avril 2002 portant révision constitutionnelle', in Journal Officiel de la République Algérienne, 41: 24.

Bouteflika, Abdelaziz (2016), Loi no $16-01$ du 26 Joumada El Oula 1437 correspondant au 6 mars 2016 portant révision constitutionnelle. Journal Officiel de la République Algérienne, 55: 14.

British and Foreign Bible Society (1904), Evangile de St. Luc (caractères arabes). Algiers: Dépôt Biblique. 
British and Foreign Bible Society (1965), The Gospel in Many Tongues: Specimens of 875 languages in which the British and Foreign Bible Society has published or circulated some portion of the Bible. London: British and Foreign Bible Society.

Brosselard, Ch. (1844), Dictionnaire français-berbère (dialecte écrit et parlé par les Kabaïles de la division d'Alger). Paris: Imprimerie Royale.

Brugnatelli, Vermondo (ed.) (2006), 'Qanun At Ali u Herzun', Wikimedia. http://commons. wikimedia.org/wiki/File:Qanun_At_Ali_u_Herzun.jpg (8 August, 2018).

Brugnatelli, Vermondo (2011), 'Some grammatical features of Ancient Eastern Berber (the language of the Mudawwana)', in Luca Busetto (ed.), Studies on Language and African Linguistics in Honour of Marcello Lamberti, Milano: Qu.A.S.A.R, 29-40. http://unimib. academia.edu/VermondoBrugnatelli/Papers/1304580/Some_grammatical_features_of_ Ancient_Eastern_Berber_the_language_of_the_Mudawwana_(8 August, 2018).

Calassanti-Motylinski, Gustave Adolphe de (1905), Le Manuscrit arabo-berbère de Zouagha découvert par M. Rebillet : Notice sommaire et extraits. Actes du XVIe Congrès des Orientalistes (Alger 1905), vol. II, Paris, 69-78.

Canton, William (1904), A history of the British and Foreign Bible Society, London: John Murray.

Chachoua, Kamel (2010), 'Radiographie de trois traductions du Coran en kabyle', in Revue des mondes musulmans et de la Méditerranée, 128: 231-245. doi:10.4000/remmm.6924 (1 October, 2013).

Chafik, Mohamed (1990), Al-MuSjam Al-SArabī Al-'Amāzīghī. Rabat: Al-MaYārif Al-Jadīdah.

Creusat, P. J.-B. (1873), Essai de dictionnaire français-kabyle (zouaoua), précédé des éléments de cette langue. Algiers: Adolphe Jourdan.

Cuendet, Eugène, T Hocart and H. G Lamb (1893), Indjil n'Sidna-Aisa el-Masih'akken itsouaḱtheb s'Marqous. London: Printed for the British and Foreign Bible Society.

Daumas, Eugène (1847), La Grande Kabylie: Etudes historiques. Paris: Hachette.

Delaporte, J.H. (1836), 'Vocabulaire berbère', in Journal Asiatique, 97-122.

Dirèche, Karima (2007), 'Les écoles catholiques dans la Kabylie du XIXe siècle', in Cahiers de la Méditerranée, 75: 17-27 (1 October, 2013).

Ferad, Mohamed Arezki (2003), 'Azaffūn: Tārīkh wa thaqāfah. Tizi Ouzou: Dār al-Amal.

Ferad, Mohamed Arezki (2004), Al-'Amāzīghiyyah: “ārā"... wa-'amthāl (Tībāzah namūdhajan). Algiers: Dār Hūmā.

Ferad, Mohamed Arezki (2007), "Ițlālah Salā Manțiqat al-Qabā"il. Tizi Ouzou: Dār al-’Amal.

Ferad, Mohamed Arezki (2011), Al-Ḥāj Muhammad al-SaYĩd Tāzrūt: "Iṭlālah Yalā al-ShiSr al-Ṣūfĩ al-"Amāzīghī. Tizi Ouzou: Dār al-'Amal.

Feraoun, Mouloud (1960), Les poèmes de Si Mohand. Paris: Editions de Minuit.

Gaci, Zohra (2011), Quel système d'écriture pour la langue berbère (le kabyle) ? Tizi Ouzou: Université Mouloud Mammeri de Tizi Ouzou Mémoire de Magister. http://www.ummto.dz/ IMG/pdf/MEMOIRE_GACI_Zohra.pdf.

Gahlouz, Mustapha (2011), Les qanouns kabyles : Anthropologie juridique du groupement social villageois de Kabylie. Paris: L'Harmattan.

GEHIMAB (2006), Les Manuscrits de Langue Berbère de la Kabylie. Bejaia: GEHIMAB. http:// www.gehimab.org/depliants/depliants/depliant21.pdf.

Gourliau, Ernest (1893), La conversation française-kabyle, dialecte zouaoua, avec figuration en caractères latins. Miliana: Légendre.

Gutova, Evgeniya (2011), The Sanusi Creed in Kabyle Berber: Manuscript KA 21 from the Lmuhub Ulahbib Library, Leiden: University of Leiden MA thesis. 
Haddadou, Mohand Akli (2004), L'alphabet berbère : Des écritures libyques aux transcriptions modernes. Béjaïa: Azur Editions.

Hanoteau, Adolphe (1858), Essai de Grammaire Kabyle. Paris: Challamel.

Hanoteau, Adolphe (1867), Poésies populaires de la Kabylie du Jurjura. Algiers: Bastide.

Heggoy, Alf Andrew (1973), 'Education in French Algeria: An Essay on Cultural Conflict', in Comparative Education Review, 17(2): 180-197 (4 November, 2014).

Hodgson, William B. (1834), 'Grammatical Sketch and Specimens of the Berber Language: Preceded by Four Letters on Berber Etymologies', in American Philosophical Society, 4: 1-48.

Hrouch, Mouhoub, Ali Lounis, Remdane Achour and Kebir Boussaad (2010), Ad lis-iw $n$ tmaziyt: aseggas wis rebsa n ulmud amenzu. Algiers: Office Nationale des Publications Scolaires.

Huyghe, G. (1901), Qamus qbaili-rumi / Dictionnaire kabyle-français. Paris: Imprimerie Nationale. Ibn Ḥamādūsh, ؟Abd al-Razzāq Muḥammad (2001), Kashf al-Rumūz fī Sharḥ al-ৎAqāqīr $w$-al-'ASshāb, Beirut: Dār al-Kutub al-ৎllmiyyah.

Ibn Khaldūn, Abū Zayd `Abd al-Raḥmān ibn Muḥammad (1969), The Muqaddimah: An Introduction to History. (Abridged Edition). (Ed.) N. J. Dawood. (Trans.) Franz Rosenthal. Princeton: Princeton University Press.

Khouas, Ahmed Ben (1881), Notions succinctes de grammaire kabyle, rédigées sous la direction du Sous-Préfet de Tizi-Ouzou et avec l'autorisation de M. le Préfet d'Alger. Algiers: Adolphe Jourdan.

Lakhdari, Samira (2013), 'Ibn al-Faqīr' en Mulud Fereun es Teqbaylit. Ech Chaab. http:// www.ech-chaab.net/ar/2012-06-09-14-44-43/\%D8\%A7\%D9\%84\%D8\%A3\% D9\%85\%D8\%A7\%D8\%B2\%D9\%8A\%D8\%BA\%D9\%8A\%D8\%A9/item/5108\%C2\%AB\%D8\%A7\%D8\%A8\%D9\%86-\%D8\%A7\%D9\%84\%D9\%81\%D9\%82\%D9\%8A \%D8\%B1\%C2\%BB-\%D8\%A7\%D9\%86-\%D9\%85\%D9\%88\%D9\%84\%D9\%88\%D8\%AF\%D9\%81\%D8\%B1\%D8\%B9\%D9\%88\%D9\%86-\%D8\%A7\%D8\%B3-\%D8\%AA\%D9\%82\%D 8\%A8\%D8\%A7\%D9\%8A\%D9\%84\%D9\%8A\%D8\%AB.html.

Luciani, Jean Dominique (1893), 'El-H’aoudh : Manuscrit berbère de la Bibliothèque-Musée d'Alger', in Revue Africaine, 37: 151-180.

Luciani, Jean Dominique (1899), 'Chansons Kabyles de Smaïl Azikkiou', in Revue Africaine, 43: 17-33.

Mammeri, Mouloud (1976), Tajerrumt $n$ tmazight (tantala taqbaylit), Paris: Maspéro.

Mechehed, Djamel-Eddine (2007), 'L'organisation des notices de catalogage des manuscrits arabes ou berbères : cas de la collection Ulahbib, Kabylie', in Les manuscrits berbères au Maghreb et dans les collections européennes. Atelier Perrousseaux.

Millot, Louis (1922), 'Le qanoun de Maâtqa', in Hespéris, 2: 193-208.

Millot, Louis (1928), 'Le qanoun des Aït Hichem', in Mémorial Henri Basset. Nouvelles études nord-africaines et orientales, 153-167. (Publications de l'Institut Des Hautes-Études Marocaines XVIII). Paris: Paul Geuthner.

Ministry of Education (2003), Al-Wathīqah al-Murāfiqah li-Manāhij Māddat al-Lughah al-Amāzīghiyyah bi-l-Lughah al-ৎArabiyyah. http://www.onefd.edu.dz/programmes/ MOYEN/MOYEN/2AM/AmazigheA.htm.

Mouliéras, Auguste (1892), Les fourberies de Si Djeh'a, Paris: Ernest Leroux.

Mouliéras, Auguste (1893), Légendes et contes merveilleux de la Grande Kabylie. Paris: Ernest Leroux.

Newman, Francis William (1847), Third chapter of Matthew, in the Kabail (or Algiers) dialect of Berber ... translated by F.W. Newman. In James Richardson (ed.), Third chapter of Matthew in the Ghadamsi dialect [by Ibn Mūsā ibn al-Qāsim], decyphered, punctuated 
and translated by F.W. Newman, ... - Third chapter of Matthew, in the Kabail (or Algiers) dialect of Berber ... translated by F.W. Newman - Familiar conversations in four languages: English and Arabic and Ghadamsee and Touarghee [by Ibn Mūsā]. - Vocabulary in Arabic and Ghadamsee [by Ibn Mūsā]. - Fragment of Grammar. The Ghadamsee and Touarghee languages. - ... Ben Mousa el-Kasem of Ghadames. London: T. E. Harrison.

Olivier, P. (1878), Dictionnaire français-kabyle. Le Puy: Freydier.

Ould-Braham, O. (1986), 'Un qanoun kabyle recueilli au XIXe siècle', in Etudes et Documents Berbères, 1: 68-77.

Radio 2. Al-'Id̄āYah Al-Jazā'iriyyah / Al-Qanāh Al-T̄āniyah. http://www.radioalgerie.dz/ar/ chaine2 (2 October, 2013).

Rebahi, Sadek (2009), Qașā’id ShiYriyyah fī al-BuYd al-Rūhī li-l-Turāth al-’Amāzīghī. In Ministry of Religious Affairs and Waqfs (ed.), Al-Multaqā al-Rābiৎ li-l-BuSd al-Rūhī fĩ al-Turāth al-Wațanī al-'Amāzīghī: Mukhtașarāt al-Mudākhalāt, 53-54. Bejaia: Ministry of Religious Affairs and Waqfs.

Rinn, L. (1887), 'Deux chansons kabyles sur l'insurrection de 1871', in Revue Africaine, 31: 55-71.

Rubrique Radar (2013), Louable initiative du journal arabophone : Le quotidien "Echaâb" lance une page en tamazight. Liberté. http://www.liberte-algerie.com/radar/le-quotidienechaab-lance-une-page-en-tamazight-louable-initiative-du-journal-arabophone-195254.

Rutherfurd, John, and Edward H. Glenny (1900), The gospel in North Africa : in two parts. London: Percy Lund, Humphries. http://archive.org/details/gospelinnorthafr00ruth.

Sedira, Belkassem Ben (1887), Cours de langue kabyle, Algiers: Adolphe Jourdan.

Sini, Chérif (2004), 'Quelle graphie pour écrire tamazight? Les raisons d'un choix', in Nouvelles études berbères (II) - Le verbe et autres articles (Berber Studies, 8), Cologne: Rüdiger Köppe, 159-170

Ṭabarkān, Salwā (2012), Al-'Alghāz al-ShaSbiyyah al-Qabā'iliyyah bi-mințaqatay Wāḍah wa-SAzāzgah (Muqārabah niyāsiyyah). Tizi Ouzou: Université Mouloud Mammeri Masters' thesis. http://www.ummto.dz/IMG/pdf/MEMOIRE-3.pdf.

Tagamount, Azzedine (ed.) (1995), Dictionnaire de Tamaziyt : Edition trilingue Tamaziyt-Français-Arabe / Munjid al-Lughah al-'Amāzīghiyyah, thulāthī al-lughāt: al-'Amāzīghiyyah, al-Faransiyyah, al-SArabiyyah. Reghaia: Berti.

Ṭayyib, Sī Ḥājj Muḥand Muḥand (2012), Al-Qur'ān al-Karīm wa-Tarjamat MaYānīhā "ilāa l-Lughah al-"Amāzīghiyyah [al-Lahjah al-Qabā'iliyyah] / Leqran leaḍim d uterjem n lemeani-is yer Iluya n tmaziyt (s teqbaylit). (Ed.) Riḍā Būshāmah and Muḥammad Ṭāhir Tĩqammūnīn. Madinah: MujammaS al-Malik Fahd li-ṬibāYat al-Mașḥaf al-Sharīf.

United Nations (1955), Demographic Yearbook 1955. New York: Statistical Office of the United Nations, Department of Economic and Social Affairs.

Al-Warțīlānī, Al-Ḥusayn ibn Muḥammad (1994), Nuzhat al-'Anđ̣ār fĩ Fạ̣l SIllm al-Tārīkh wal-'Akhbār. (Ed.) Muḥammad Ibn Abī Shanab. (Al-Jug̉rāfiyā Al-'Islāmiyyah 192). Frankfurt am Main: Institut für Geschichte der Arabisch-Islamischen Wissenschaften.

Yacine, Tassadit (1987), Poésie berbère et identité : Qasi Udifella, héraut des At Sidi Braham. Paris: Editions de la Maison des Sciences de l'Homme.

Zeroual, Liamine (1995), 'Décret présidentiel n 95-147 du 27 Dhou El Hidja 1415 correspondant au 27 mai 1995, portant création du Haut commissariat chargé de la réhabilitation de l'amazighité et de la promotion de la langue amazighe', in Journal Officiel de la République Algérienne, 34: 29. 